\title{
The challenge of ageing in tomorrow's Britain $†$
}

\author{
MIRIAM BERNARD* and JUDITH PHILLIPS*
}

\begin{abstract}
Some 50 years after the creation of the welfare state and at the start of the new millennium, this paper considers the current and future status of older people in Britain. It argues that as the population ages, the situation of older people is becoming an increasingly important element in social policy debates. The first half of the paper critically reviews developments over the last five decades, emphasising the salience of accommodation issues during this period. In the light of recent initiatives such as 'Better Government for Older People', the second half of the paper outlines a policy agenda for the early years of the 2 ist century. We argue unequivocally for an integrated social policy which addresses the broad needs of an ageing society as opposed to narrow age-based interests, or the interests of specific problematised or stigmatised groups. The creation and delivery of such an integrated policy for tomorrow's Britain rests, we contend, on three crucial dimensions: an explicitly articulated value base; a consideration of the educational, technological and spatial aspects of policy; and harmonisation of action at both local and national levels.
\end{abstract}

$\boldsymbol{K} \boldsymbol{E} \boldsymbol{Y} \boldsymbol{W} \boldsymbol{O} \boldsymbol{R} \boldsymbol{D} \boldsymbol{S}$ - Older people, ageing, integrated and critical social policy, welfare state, health and social care.

\section{Introduction}

The purpose of this paper is twofold: first, we trace the major shifts which have occurred since the euphoric beginnings in the UK of the welfare state and the creation of the National Health Service, drawing these strands together into a review of major policy developments during this period. Second, we consider what form a social policy of ageing might take in the new century. The paper begins by sketching in the background to post-war welfarism and critically evaluating developments from the i 950 os to the r $970 \mathrm{os}$ : a period during which issues

* Centre for Social Gerontology, Keele University

$\dagger$ This paper is an amended and shortened version of the review and arguments we put forward in the opening and closing chapters of our (1998) book: The Social Policy of Old Age - moving into the $2 I^{\text {st }}$ century. The publishers of this book, the Centre for Policy on Ageing, have given permission for the material to be reproduced here. 
of accommodation for older people (both institutional forms and community-based alternatives) were to dominate the social policy agenda, alongside continuing concerns over pensions. We then chart the changing policy agenda of the r 970 and ig8os which, for older people, has meant a breaking of the 'welfare compact' between the generations; an emphasis on market solutions; the unregulated growth and expansion of the private and independent sectors; and the 'discovery' of informal carers. Turning to the end of the 2oth century, we go on to argue that this has proved to be a particularly difficult time for the development and implementation of social policies affecting older people. Although we have witnessed the coming together of demographic changes with a growing social and political awareness of ageing, policy in the I99os has been characterised by increasing tensions and contested ground over issues such as pensions, poverty, health and social welfare, leisure and education.

In the second half of the paper, we turn our attention towards policy development in the new millennium. This discussion is premised on the belief that the kind of society we might wish to see, and the social policies which that society promotes and espouses, are for us all to shape and mould. We argue unequivocally for an integrated social policy which addresses the broad needs of an ageing society, as opposed to narrow age-based interests, or the interests of specific problematised or stigmatised groups. In so doing, we provide a rationale for why we feel that such an integrated approach is long overdue. We then go on to discuss the values and philosophy which underlie and inform this approach, and highlight three key areas that we regard as crucial to the establishment of this new policy agenda for ageing in tomorrow's Britain: an explicitly articulated value base; a consideration of the educational, technological and spatial aspects of policy; and harmonisation of action and policy at both local and national levels.

\section{Warfare, welfare and the new literature on old age}

Many observers on the social policy scene point to the period from about I870 to I940 as a time of 'creeping collectivism' (Midwinter I 994; Sullivan I 996), marked out by increasing state intervention and support for large-scale institutional solutions to social needs. Society was becoming increasingly urbanised and industrialised, and was underpinned by a large working class. Pensions policy was a key area for consideration at this time, with means-tested state pensions for those

over the age of 70 , being introduced in I gog. From the I 920 on onwards, 
contributory pension schemes also began to operate for particular sectors of the population, whilst national insurance cover began to address some of the problems associated with unemployment. By the outbreak of the Second World War, there were various policies and provisions in place which were to directly and indirectly affect the lives of older people: public health measures, housing legislation and illness insurance, in addition to the old age pension. These then were the immediate forerunners of the welfare state whose arrival, both during and immediately after the war years, was to herald radical changes for British society in general, and older people in particular.

The Beveridge Report of 1942 signalled this critical period of social change. Emerging from a growing consensus about the inadequacy and irrationality of the existing health and social welfare system, Beveridge recommended tackling his 'Five Giants' (want, idleness, squalor, ignorance and disease), through the reform and extension of the social security system and the creation of a national health service. Whilst older people had always featured in these social policy debates (Walker and Phillipson I986), particularly in demographic terms, in other respects they can be seen at this time as being increasingly marginalised and excluded, sometimes literally so. For example, during the war years many elderly patients were being discharged wholesale from hospitals to make way for war casualties, whilst large numbers of elderly people in the cities were being left homeless by the air raids. Together, these factors meant that the existing Public Assistance Institutions (the workhouses) were becoming seriously overcrowded; in fact, nearly 400 of them still existed, accommodating more residents than they had done at the start of the century. Even with the Health White Paper in I944, the passing of the National Health Services Act in I946, and Seebohm Rowntree's seminal inquiry (1947), reforms were slow in coming. The pervasive issues where social policy and older people were concerned, remained those of poverty and destitution (Parker i 990).

Indeed, the Labour governments of I 945 to I95 I, were faced with the task of developing social policies against a background that was profoundly influenced by the economic difficulties attendant on postwar reconstruction (Sullivan, I996). With regard to the situation of older people, it is evident that despite the optimism embodied in the I 948 National Assistance Act, the reality fell some way short of this. Indeed, as Robin Means ( I986: 88) has argued, 'few social policy academics have had a kind word to say about the I948 Act', and its effect on the subsequent development of welfare services for elderly people. Although the three Conservative administrations from I95 I 
until I 964 were apparently committed to furthering the development of the welfare state, social policy during the i 950 os and i 960 s effectively became divorced from the range of needs of older people. We can identify several reasons for this.

First, provision for the welfare of older people lacked a conceptual framework. There was no clear direction for social policy, with the legacies of the Poor Law system persisting well into the ig6os. Despite the 'reforms' embodied in the I 948 Act, there continued to be complete reliance on residential care as the solution to the needs of older people, even though community care had been around as a concept since the I 940 os. In reality, there was a lack of political commitment to its development, even given the growing critique of policy from Crosland (1956), Marshall (I965), Titmuss (1968) and others. This critique, together with the emergent research evidence, suggested that families and, in particular, daughters would not in fact abandon care of their older parents if the state switched its focus to community care (Townsend i963). But, the impetus for developing alternatives was slow.

Second, despite the lack of a coherent rationale for residential care, there was an inbuilt inability to move to community care because of the huge resources already committed to its perpetuation. Substantial capital investment in buildings deterred flexibility, and a strong residential care lobby ensured that resources were not diverted elsewhere. Third, there was actually comparatively little research attention given to the experiences of older people living in residential care in the I95os. Even when the graphic and highly negative accounts of Townsend in The Last Refuge (1962) and of Robb in Sans Everything ( 1967 ) surfaced in the public domain, action was directed at the institutions and their building regulations, rather than at the situations of individuals and standards of care.

Finally, and closely related to the above three reasons, was a (continuing) lack of clear boundaries between health and social care. One consequence of this was that during the i95os and ig6os, many older people suffered inappropriate admission to hospital or residential care, whilst others who needed residential care remained at home. Local authority procedures for admission to residential care reflected a service-led rather than needs-led approach, with older people exercising very little choice.

In essence, social policy as it affected older people at this time, can be seen as heavily focused on residential care, with older people continuing to receive a 'Cinderella' service (Means and Smith i 985). 
One of the main criticisms of this period, therefore, is the lack of vision among many social policy analysts and sociologists who reframed residential care as 'the last resort' but without suggesting any realistic alternatives to put in its place.

\section{The changing social policy agenda of the $1970 \mathrm{~s}$ and $1980 \mathrm{~s}$}

A lack of co-ordination and strategic planning with other sectors of welfare, continued on into the ig7os. There were, however, signs that the appropriateness of residential care for older people was being questioned. Several additional factors contributed to this, the most dominant being the effects of the $1973 / 74$ oil crisis on welfare expenditure. Amongst the consequences were restrictions in local authority building and the development of rationing systems which excluded active older people. Institutional care was increasingly portrayed in a harsh light, deterring entry and thus helping to persuade people to accept inadequate community services, which were often seen as cheaper since they relied on the family rather than the state. Furthermore, the pervasive negative images of older people as dependent and disabled led many professionals, such as social workers, to develop their interests in other groups in society. Indeed, work with older people was regarded in certain quarters as a form of professional suicide (Phillipson I 982).

Progress towards community care in the I 970 os was painfully slow as social policy attempted to move from a position of maintenance to one of prevention - enabling people to live at home as long as possible through the expansion of domiciliary services, such as home helps and meals-on-wheels. Although several policy documents stressed the importance of community care, initially there was little widespread impact on services. Even with the reorganisation of personal social services in the I97 I Seebohm reforms, when work with older people was brought into the mainstream of social work activity, public sector residential care was still the major provision for older people (Means and Smith i 985). By contrast, domiciliary care initiatives remained localised. There was a widespread assumption that such services would undermine the willingness of families to care and, in addition, there was a belief amongst many professionals that domiciliary care would not in fact be cost effective and would be unable to expand sufficiently to replace residential care (Means i986). In essence, no substantial financial commitment was made to a realistic community care alternative. It was only when economic and demographic imperatives 
re-surfaced, fuelling a moral panic about the growing 'burden of dependency' older people represented, that social policy debates were once more driven forward into the ig8os.

In the wake of the conservative election victory in I979, privatisation, competition and the development of what Le Grand ( I990) calls the 'quasi-market', anti-state and decentralisation of services, were the order of the day. The state was left to regulate, finance and co-ordinate care for older people and other vulnerable groups. Alongside this, the demographic 'time bomb' again raised its head, calling into question the ability of the state to sustain a growing dependent population. This view was encapsulated in 1983 with the appearance of $A$ Rising Tide in which it was predicted that the health care system would be overrun by the projected large numbers of old people suffering from dementia (Health Advisory Service I983). At the same time, the traditional relationship between the state and the family was also being challenged. Policy was seen as 'rolling back the frontiers of the state' with increasing reliance being placed on families and on the private sector.

As the decade progressed, however, there were increasingly vocal debates about the extent of choice in the private sector. Documentary evidence began to expose some of the poor standards of care and exploitation of older residents, and led to the Registered Homes Act ( 1984 ) and the introduction of an advisory code of practice: Home Life (CPA I 984). This Act in fact placed the state in a contradictory position: it was required to 'police' the private sector whilst, at the same time, being urged to develop a partnership approach with the very same people. Ironically, this situation contributed to a gradual reviewing and re-framing of old age, which began to take hold on the welfare agenda. Social policy itself was increasingly vacillating between seeing older people as dependent social casualties, and seeing them as individuals capable of exercising choice. In the private sector, older people were viewed - in theory at least - as customers with rights, in contrast to the state sector which, its critics argued, fostered dependency, harboured abuse and was paternalistic as well as ignorant of the wishes of older people. The changes introduced by the Thatcher administrations of the ig8os, began to challenge the key relationship between the state and older people, revolutionising the fundamental principles which had underpinned policy since the I940s. This led, in turn, to the appearance of four influential reports which appeared rapidly one after another: a highly critical Audit Commission report (1986); the Firth Report (DHSS I987); the Wagner Report on residential care (I 988); and the Griffiths Report (I 988). These set the scene for the White Paper and subsequent NHS and Community Care 
Act (I990) which, as we shall see below, was the most influential piece of social policy legislation to affect the lives of older people in the i 990 s.

\section{Policies on ageing: the place of old people in the society of the I990s}

Essentially, the NHS and Community Care Act (I990) attempted to distil the findings of earlier critical reports and inquiries, and to lay the ground for a system which would move social policy irrevocably away from universal welfare provision, to more selective, targeted and accountable services. It is remarkable that within the space of 40 years, we had moved from an inquiry into the situation of old people and associated social policy implications conducted under the auspices of a 'social investigator' (Rowntree I947), to a contemporary review undertaken from the perspective of a consummate businessman (Baldwin I 993). This in itself speaks volumes about how, at the close of the Thatcher years, social policy was still being narrowly constructed from a basis of entrepreneurialism.

What is also striking about the NHS and Community Care reforms is that, despite their origins in a very different ideological perspective from that which pertained in the r 940 , they too were couched in a recognition that public expenditure cannot, and should not be a bottomless pit, and that some attempt has to be made to balance the claims of different sectors of the population. In essence, this is not a million miles away from either Beveridge or Rowntree. Moreover, half a century later, the Act itself further illustrates how social policy in the I 990 s has been characterised by the emergence of a new language. Terms such as empowerment; advocacy; user involvement and participation; consumerism; care management; purchasers and providers; enablers and facilitators; internal markets; and packages of care, to name but a few, have come into everyday parlance. However, behind the rhetoric of this new language we can discern the continuing erosion of state responsibility for the care of older people. Alan Walker (I993) amongst others, has argued that the 'new community care', imposed from the top down, is mainly concerned with cost containment and management issues; that it fragments services, and is more about targeting than rights. Indeed, Higgs ( I 995) shows how 'rights' have all but disappeared as services have withdrawn still further, and older people without financial or personal resources have been faced with very little choice over their lives. As the state withdraws further and further from provision, unregulated services (particularly in domi- 
ciliary care) proliferate. Increasingly too, the focus has been on what the appropriate balance between the state and the individual might be in terms of financing care in old age. This meant that in late 2oth century Britain, pension provision again assumed a particular salience in policy terms, against an ever-present background of discussion about health and social care (Walker i 996).

Moreover, hard questions continue to be asked about whether older people are, in some way, 'consuming more than their fair share of society's resources to the detriment of younger groups, particularly children' (Vincent I995: I 40). Proponents of this position employ the arguments of 'apocalyptic demography' in an effort to justify reductions in the state pension and thereby reduce government expenditure. However, because of the generalised ways in which this debate still persists in viewing older people, it is evident that certain sectors of the older population - notably older women, and black and minority ethnic elders - will continue to be disadvantaged. Indeed, many critical commentators argue that much contemporary social policy making actually exacerbates the inequalities which exist amongst older people, and that these inequities are likely to continue well into the future (Evandrou I997). It is thus to this future that we now turn in the second half of the paper.

\section{Ageing in tomorrow's Britain}

For far too long, social policy in Britain has been bedevilled by piecemeal and ad hoc approaches. Moreover, 'policy' aimed specifically at addressing the needs of older people has suffered - and indeed still suffers - from being very narrowly conceived. At the start of a new millennium, Britain once again faces a 'new situation', but a situation which in our view calls not for a policy 'which will give the most help to retired people' (Bosanquet i 978: 77), but for one which addresses the diversity of needs of an ageing society. This is a rather different kind of policy orientation from one that targets those whom we label 'old' or 'retired'. It means that we have to move away from traditional and polarised views that conceive of older people as either 'the deserving poor' in need of a safety net of social protection; or as a burden on, and cause of, the potential impoverishment of other groups. Rather, it attempts to recognise, and build upon, the diversity and interdependence of individuals, whilst at the same time acknowledging that we all, irrespective of our chronological age, have a common purpose in fashioning an integrated social policy which is about supporting all of us to live in an ageing society. 
Before examining ways in which it might be possible to move towards such a policy orientation, we consider two sets of pressures which, in our view, make the need for an integrated policy for the new millennium essential. The first has to do with the continuing impact of demographic change in general, and population ageing in particular. The second concerns the coming together of demographic pressures with the economic, social and political realities of contemporary life.

\section{Demographic imperatives}

In terms of the demographic imperatives, it is important to remind ourselves that never before have we been such an 'old' society (Laslett I 996) and that, alongside increasing life expectancy, ageing is also a progressively gendered experience. Whilst there are more old people in Britain's population than ever before (almost one in every five people are over pensionable age), what seems to be less appreciated is that this population is itself ageing. The total number of people over pensionable age is projected to grow fairly slowly for the foreseeable future, picking up slightly over the first decade of the new millennium with a rise of nine per cent - an additional one million people (OPCS I997). However, it is the numbers of people aged 75 and over, and 85 and over, which will increase most markedly - the former being predicted to double in size by the middle of the century, and the latter to triple. Moreover, percentage increases are greater the older the age group one considers. In I 994, for example, 8,000 people in the United Kingdom (7,00o women and I, ooo men) were aged i oo years or older (OPCS I 997). By 203 I, it is estimated that 28,000 women and 6,000 men will be this old: a 425 per cent increase over today's figures.

This highlights a further important feature about our ageing population: namely, that later life is clearly dominated - in numerical terms at least - by women. At age 75 and over, women outnumber men by 2 to I; at 85 and over by 4 to I ; and, at the age of Ioo, by 7 to I. Despite the gradual closing of the life expectancy gap, this gender imbalance will remain of crucial importance in policy terms. Furthermore, census comparisons and demographic trends suggest that over the coming decades there will be a steep growth in the numbers of older people in Britain of Asian and Afro-Caribbean origin, and that the numbers can no longer be dismissed as being too small to cause concern in respect of policy and practice (Atkin I998).

Although Britain will continue to age, the last three decades of the 2oth century, have in fact witnessed the most rapid ageing of our population. In some sense then it is possible to argue that demography, whilst still important, may be less so in the early decades of the new 
century. Indeed, it is the conjunction of these demographic trends with changes to the social, economic and political circumstances of our ageing population, which is likely to have the greatest influence.

\section{Social, economic and political realities}

Older people today find themselves in a very diverse set of circumstances. Alterations to the structure of the population have been accompanied by profound changes in the size and composition of the family, as the effects of lowered fertility and increasing divorce begin to make their impact felt on the older generations. Changes to living arrangements, the increasing numbers of widows and widowers in old age, and the rise of solo living have all become more prominent - and are expected to continue to be so. Women's increased labour market participation and the rise in membership of occupational and private pension schemes, will likewise have substantial impacts as we move into the new century.

Alongside demographic changes, economic factors are powerful influences. But, the reality today is that old age is not the great leveller it was once assumed to be. On the contrary, there are substantial and persistent inequalities which need to be urgently addressed at a policy level (Phillipson I998). Here, financial security in general, and pensions policy in particular, are crucial. With respect to pensions, it is our belief that if the present arrangements continue, then the inequalities which have become glaringly apparent in Britain over the last decade will be further exacerbated in the new century. Claims that we need state pensions less and less because more elderly people are in receipt of non-state pensions, are patently untrue: two-thirds of men may be in this position, but three-quarters of women are not (Ginn and Arber i 996).

Similarly, we would suggest that radical alterations to the funding of health and social care over the last 20 years, have irrevocably changed the face of British welfare for older people. Increasing privatisation, with its accompaniments of charging for services and the rationing (explicitly or otherwise) of publicly-funded health care, has led to marked inequalities in access. Moreover, it is patently clear that the kinds of health and social care we may see in the new century, will be fundamentally linked to the political choices we make and to the impact of increasing globalisation. This suggests that, whereas today we may be primarily concerned with policy at national and local levels, the 'boundaries' of future policy may in fact be much wider.

The reality then, at the start of the new millennium, is a mixture of 
certainties and uncertainties: the certainties are that younger and older generations alike currently live in a very diverse set of circumstances. The uncertainties concern whether, and in what ways, these circumstances may change in the future. Some of this is predictable; much more though is unpredictable.

However, these current realities suggest that the case for an integrated social policy of ageing, whilst it may not be profoundly new or radical (see Norton et al. I 986), is stronger now than it has ever been. The fundamental issue concerns what kind of social policy we wish to develop. Before attempting to address this, we first outline the values and philosophy which we believe ought to underlie the development of an integrated social policy of ageing.

\section{Towards an integrated social policy}

Policy, like most things, is not plucked from thin air but is the outcome of competing ideologies, values and interests. Thus, in order to shape and give form to a social policy of ageing for tomorrow's Britain, it is important to spell out the value base on which we see this approach to policy being developed. Whilst some may disagree and take issue over the details of such a value base, we believe it to be a crucial first step before looking at how we might plan for, implement, and evaluate an integrated policy framework.

The values we espouse are inter-dependent, and revolve around our commitment to four key areas:

- a positive, inter-generational, life course perspective,

- the importance of combatting all forms of discrimination,

- notions of empowerment, citizenship and voice,

- critical commentary and action.

Through the life course and across the generations

The pressures producing an increased fragmentation of the contemporary lifecourse will not go away: the concept of a lifelong career in one occupation is fast vanishing, along with earlier certainties about such things as a fixed time for retirement. This calls for much greater flexibility in how we view the lifecourse. Many commentators are now arguing for strengthened links across the generations if we are to combat what Margaret Simey (I998) notes as the possibility for intergenerational conflict as opposed to collaboration. To this, we would add our own concern that it is 'ageing' as opposed to 'old age' or 'old people', that should form a key concept around which to 
construct social policy. For too long gerontologists have exhorted the general populace that they should be interested in old age because, barring any major catastrophe, we will all eventually become 'old'. This exhortation is, more often than not, met with a kind of collective dissonance in which, ostrich-like, people metaphorically bury their heads in the sand. Old age and being old is something that happens to other people, not to us. It is something to be pushed to one side and considered, if at all, as and when we get there.

Within an intergenerational lifecourse perspective, 'ageing' therefore seems to us to have more potential than a focus on old age or old people. It is not simply a question of semantics, but an issue which goes to the heart of the other values on which we believe policy should be constructed. In other words, it begins to move us away from the idea that there is somehow a separate and distinct group we can all clearly identify as 'old'. In this context, we would also argue for the need to rid ourselves of the divisiveness of the increasingly prevalent and uncritical use of the terms 'third' and 'fourth' age. The 'Third Age', associated as it is with a healthy, active and poverty-free time in the lifecourse, has seeped stealthily into the public consciousness. This generates even greater distancing and polarisation between people in this so-called phase and those who find themselves ill, sick, impoverished and dependent in the 'Fourth Age' (or indeed growing up in the 'First Age' and raising families and working in the 'Second Age'). Again, this would help move us away from seeing particular groups simply as burdens on the state, or as 'problems to be solved'. This in turn, is inextricably linked with a commitment to combat all forms of discrimination.

\section{Combatting discrimination}

We live in a society which, despite the inroads made by legislation and codes of practice over recent decades is still, at bottom, riddled with inequalities and with hostile and discriminatory attitudes and practices (Bytheway I995; McEwen I990). The insidious impact of ageism, together with the more familiar forms of discrimination linked with race and ethnicity, gender, sexual orientation and physical and mental disability, is something which must be countered at every available opportunity.

There is, for example, considerable evidence to suggest that professionals who work with older people often hold some of the most negative and ageist attitudes of all (Evers I98 I ; Hughes and Mtezuka I992; Rees I99 I Stevenson r 989). In the health and social care arena, 
where the majority of front-line workers are women, often caring for other - albeit older - women, we also have to face the very real possibility of what one American commentator has called woman-towoman ageism (Copper I988). In situations where one is daily faced with images of what we ourselves might become in the future, it is not altogether surprising that nurses and social workers develop strategies to distance themselves from patients and clients, even to the point of colluding with, and intensifying, ageist attitudes and practices (Bernard I 998). Policy formulation is not exempt from these pressures either and, indeed, it is not unusual for the observation to be made that policy, rather than addressing discrimination, actually reinforces it.

Empowerment, citizenship and voice

Progress along this road has to be accompanied by a belief in the value of, and a firm commitment to, notions of empowerment, citizenship and voice. What we seem to be witnessing at this point, is the coming together of various pressures: pressures from older people themselves to be regarded as active consumers; pressures within professional groups to reorient their practices, to critically question their professional autonomy and to find new ways of working 'with', as opposed to just 'for', older people (Ogg et al. I 998); and political pressures which are stimulating older people to take action on their own behalf in the defence of their rights and interests as they age (Bornat i998). Older people are also increasingly 'finding a voice' by providing commentaries on existing policies and provisions and by conducting policyrelevant research (Cooper et al. i 994; Tozer and Thornton i 995).

However, the situation in Britain contrasts in a number of ways with Europe and North America. In Europe, many countries actively support hearing the voice of older people through advisory boards at local authority level, and through representatives of these boards at national level (Walker and Maltby i 997; Walker and Naegele i 999). France, Spain, Holland and Ireland all operate such systems. In the United States, where the state welfare system is much less prominent and where there is a longer-standing and more pluralistic political system, older people's interests and voices have been heard much more loudly. Mass membership organisations such as the 50 million strong American Association of Retired Persons, and the Gray Panthers, together with advocacy groups like the Older Women's League, press tirelessly for the integration of older people into the mainstream of society, as well as taking an active interest in the development of public policy (Bernard et al. I993; Older Women's League i997). 
Some might argue that this kind of principled stand is unrealistic, but there is now a growing body of evidence which attests to the importance and efficacy of such approaches, particularly when bolstered and reinforced by proper levels of practical support and access (see, for example, Bernard forthcoming; Croft and Beresford I990; Walker and Warren r996). Indeed, Alan Walker (1997), amongst others, regards the creation and promotion of what he calls a 'culture of empowerment', as crucial to current and future policymaking and provision.

\section{Critique and action}

This brings us to our last set of values: a belief that underlying policy formulation should be the means to develop a critical commentary on what is happening, in combination with action. Our own backgrounds are located in practice: in social work and in work with older people in the voluntary sector. Actively maintaining links with those whom we research and write about, as well as ensuring that the research we undertake can be used to inform both policy formation and the provision of services is, we believe, crucial.

In social gerontology, making one's value base explicit has come together in what is now labelled the 'critical gerontology' movement. On both sides of the Atlantic, publications couched within this perspective have appeared regularly during the i 990 (see for example, Minkler and Estes i 99 I, I 997; Moody r 992; Cole I993; Vincent I 995; Jamieson et al. I997; Phillipson 1998). Essentially, this viewpoint is about ensuring, in the words of Meredith Minkler ( I 996:470), that our approach is one which 'puts a human face - and a human body and spirit - on ageing and growing old'. It alerts us not only to the importance of critically examining social policy as a means of providing answers and meeting the needs of people, but also to look at it as part of the problem both now, and for the future. It is our belief that, should our academic critique of policy remain simply at the level of ideas (or even just at passing on information from what we have learnt), we shall not get very far down the road towards generating an integrated social policy of ageing.

\section{Greating an integrated social policy of ageing}

Building on the values outlined above, we believe it is important to create a new integrated social policy of ageing which moves us away from what has been an overly narrow conceptualisation of social policy 
(Cahill r 994). In the following we do not discuss in detail pensions policy, family policy or health and social welfare. These areas will undoubtedly continue to hold a persistent and prominent place in debates about the social policy of ageing. Rather, we focus on three additional areas we believe will become increasingly important in the new millennium. In our view, the creation of an integrated social policy of ageing will need to ensure that it is:

- educationally-minded;

- technologically-minded; and

- spatially-minded.

\section{An educationally-minded social policy of ageing}

An educationally-minded approach must first critically question the conventional definitions of education, work, leisure and retirement before it can begin to reformulate what impact this might have on future policy. Education, as Eric Midwinter ( 1998 ) has shown, is not just about equipping children and young people for the world of work. It is a lifelong undertaking. However, children do need, we would suggest, to be 'educated' early in life about the dimensions of ageing. For the most part, this is abysmally addressed in many of our schools and colleges, where personal and social education seems to consist largely of unimaginative and traditional, community-service-type activities: children are encouraged to do things for older people, rather than with them. There are signs, albeit piecemeal ones, that this is not the case in every school or college. The rg9os have witnessed some pioneering projects, for example in oral history and the mentoring by older people of children with particular difficulties. These projects have been led primarily by voluntary organisations such as the Beth Johnson Foundation and Age Concern (see too O'Connor i 993). Yet, British developments lag behind what is happening in North America where there is a substantive body of work concerned with bringing the generations together in mutually beneficial school-based projects (Newman and Marks i980; Carstensen et al. i982; Lyons et al. i984; Aday et al. I99 I Newman et al. I997). Britain can learn much from these developments: they are a prerequisite if we are to begin the process of changing attitudes towards ageing and older people, and inculcating a sense that 'ageing' concerns all of us.

This must also carry through into other sectors of our education system. In keeping with what we have already said, such education should include, and be underpinned by, an examination of attitudes and motivations. However, simply teaching about attitudes and about 
ageism is insufficient: it has constantly to be reinforced and reexamined through critically reflective practice. Moreover, what has become alarmingly evident over recent years, is that the inroads which were being made through the creation and expansion of postgraduate and post-qualifying programmes in gerontology, are now suffering cutbacks in Britain as professionals find it ever more difficult to get even partial funding for such studies. This situation is all the more lamentable given the demographic changes which are happening in concert with social, political and economic transformations.

Work and retirement too have been radically transformed and we would suggest that hard questions need to be asked both about what it is we understand by these concepts, and whether it is still realistic, in policy terms, to underpin society with the goal of full employment. Even though 'full employment' today is not the same thing as envisaged by Beveridge, it is still a very conventional and male-oriented basis around which to organise the creation of new social policy. Work and retirement seem to us to be outmoded terms, especially given the variety of forms that 'work' now takes, and the inapplicability of the notion of 'retirement' to many people today. Policy creation must be about helping us all to determine what sort of balances we might want individually, and collectively, between paid work, education and training, unpaid work, and leisure, and how these might be balanced with other lifetime commitments, for example to the family.

If the worlds of education, work and retirement have undergone major changes over the last 50 years, and look set to continue to change in the future, then one of the forces behind this has been the impact of technological developments.

\section{A technologically-minded social policy of ageing}

Maria Evandrou ( I 998) has observed that technology is not something we can ignore in the new century, and we too would argue that technology should be at the heart of social policy for several reasons. First, it is intergenerational in the sense that technology has the ability to improve the situation and quality of life for all people. Secondly, technology is important to a social policy of ageing because it pervades every aspect of life and has the potential for assisting with many of the 'traditional' problems associated with ageing. Communications, clothing, house design, shopping and medicine are areas all now influenced by technology. The concept of 'lifetime' or 'lifelong' homes could be copied in many other spheres of life (Peace and Johnson I 998), whilst designing with ageing in mind at home, at work, or in the 
supermarket will benefit younger as well as older people. Thirdly, technology is pluralistic and preventative. It is about facilitating communication which can enable people, of whatever race, age or gender, to participate as citizens in decision-making and can empower people as they shop, vote and seek expert help 'on line' in all areas of policy. Technology can assist us to overcome some of the barriers already noted between conventional policy areas such as housing, health and social services, education and work, in order to help create a 'seamless' service (Griffiths i 988 ).

All areas of social policy are potentially affected by technological change. In particular, the technological revolution has altered the relationship between the individual and the spaces and places within which we live out our lives. Finally then, we turn to a brief discussion of the spatial aspects of a social policy of ageing.

A spatially-minded social policy of ageing

In our view, a much closer relationship is needed between the social and spatial aspects of ageing. To date, the spatial dimensions of ageing have been neglected in social policy terms. Yet, ageing and old age are intimately associated with places and spaces, be they the day centre, a retirement home, or one's own home. Most existing discussions concentrate on the traditional aspects of location, proximity and territorial inequalities (Townsend and Davidson i986; Whitehead i 987; Joseph and Hallman i996; Dorling i997). More recently however, increasing attention has been paid to the psychological aspects of space. Glenda Laws ( I997) for example, describes age specific locations in the United States, and argues that identities in old age are created and maintained by older people's location. She draws on the example of Sun City, where the spatial segregation of older people is considered alongside the promotion of a positive, healthy image. Similar examples of housing communities are growing in Britain (Biggs et al. I998), and there is a need urgently to consider the impact of space on ageing.

Beyond location, proximity and territorial inequalities, we argue for a broader conception of the spatial dimension in social policy. Other developments that make an impact on people's sense of space and place should be examined, such as transportation, traffic planning, land use management, architecture and design. It is our belief that an explicit spatial framework for social policy can no longer be ignored, especially as people become more mobile, markets become global and technology assists in linking people, whatever their age, with identifiable places and spaces. 


\section{Conclusion: delivering an integrated social policy of ageing}

In 1954 the Phillips Report (Chancellor of the Exchequer 1954) focused on how Britain was going to meet the needs of growing numbers of older people. It made startlingly accurate demographic forecasts at the time, and drew attention to the ways in which needs, and policy responses, had to be seen as inter-related. Since then, there have been numerous surveys and inquiries including, for example, the Carnegie Inquiry into the Third Age ( I993) and the report on older women produced by the Women's National Commission (I992). Unfortunately, the recommendations of such reports are usually only 'advisory' and largely applicable to service providers as opposed to policy makers. We now need to go further and our call is for a largescale Government initiative in Britain, to bring together crossgenerational, cross-sectoral, cross-departmental and cross-party interests in the future of our ageing population. It is our belief that the time is ripe to press for a National Commission on 'integrated policies for a social policy of ageing' to be followed, perhaps, by the creation of a Ministry of Ageing.

Feeding into this national level, we would envisage something which is structurally similar to some of the initiatives that exist in Europe. In particular, we would draw attention to the need to create policymaking boards or councils at local authority level. Unlike some of the European structures however, our suggestion is that, as at national level, these consist not simply of older people, but of people of all ages and from a variety of local 'constituencies' who are concerned about these issues.

This is not to suggest that inroads are not already being made in these directions - far from it. Since the early i g9os, one of us (Bernard) has worked with members of the Warwick University Local Authorities Research Consortium, in order to help articulate some of the ideas outlined in this paper. Since r 994, the Consortium's work has involved three phases of activity: first, a survey of authorities to identify whether or not there were moves to create corporate interdepartmental strategies; second, the completion of a postal questionnaire by other agencies in these areas about the ways they are responding to ageing; and third, the presentation of these findings at a conference which called for a programme to pilot inter-agency strategies for an ageing population (Benington I998). In I998, this work came to fruition with the launch of the 'Better Government for Older People' initiative. A total of 28 projects from around the UK are taking part in a two-year

programme which is being closely monitored and evaluated by the Local Government Centre at Warwick University. 
Whilst these kinds of initiatives are undoubtedly important it will not be enough, in our view, for them to remain simply at a local project level. Mechanisms will need to be developed so that the lessons learnt can be fed into a wide-ranging overview of how we might best deliver an integrated social policy of ageing nationally. It is also important that local strategies, bringing together different departments to discuss ageing as a mutual concern, are mirrored at inter-governmental office level. The creation, in I998, of an inter-ministerial group on ageing is a step in this direction.

In conclusion, therefore, the creation and delivery of an integrated social policy of ageing rests on three crucial dimensions. First, as we have argued, it must make explicit the value base on which it is constructed. Second, in translating these values into policy, we will increasingly have to consider the educational, technological and spatial aspects of policy. Third, and arising from this, action is needed in Britain at national and local levels, all the time bearing in mind the impact of the European (and, indeed, global) context on policy formulation. Malcolm Wicks (1994: 288) has observed that: 'It was the historic role of the Labour government of i 945 to serve as midwife to modern social policy'. Now, another Labour government has the opportunity to fashion a new integrated social policy of ageing which will address the interests and concerns of all citizens as we move into the 2 ist century.

\section{References}

Aday, R. H., Sims, C. R. and Evans, E. i99 I. Youth's attitudes toward the elderly: the impact of intergenerational partners, Fournal of Applied Gerontology, ro,3, 372-84.

Atkin, K. 1998. Ageing in a multi-racial Britain: demography, policy and practice. In Bernard, M. and Phillips, J. (eds) The Social Policy of Old Age - Moving into the $2 I^{\text {st }}$ Century. Centre for Policy on Ageing: London.

Audit Commission. i 986. Making a Reality of Community Care. HMSO: London.

Baldwin, S. I 993. The Myth of Community Care: an Alternative Model. Chapman and Hall: London.

Benington, J. 1998. Local Strategies and Initiatives for an Ageing Population. Warwick Business School and the Warwick University Local Authorities Research Consortium: Warwick.

Beveridge, W. i 942. Social Insurance and Allied Services. Cmnd. 6404. HMSO: London.

Bernard, M. I998. Backs to the future?: Reflections on women, ageing and nursing', Fournal of Advanced Nursing, 27, 633-40.

Bernard, M. in press. Promoting Health in Old Age: Critical Issues in Self Health Care. Open University Press: Buckingham.

Bernard, M., Meade, K. and Tinker, A. I 993. Women come of age. In Bernard, M. and Meade, K. (eds) Women Come of Age: Perspectives on the Lives of Older Women. Edward Arnold: London.

Biggs, S., Bernard, M. and Kingston, P. 1998. Assessing the Health Impact of Age-specific Housing - Interim Report. Keele University: Department of Applied Social Studies. 
Bornat, J. I 998. Pensioners organise: hearing the voice of older people. In Bernard, M. and Phillips, J. (eds) The Social Policy of Old Age - Moving into the $2 I^{\text {st }}$ Century. Centre for Policy on Ageing: London.

Bosanquet, N. 1978. A Future for Old Age. Temple Smith/New Society: London.

Bytheway, B. I995. Ageism. Open University Press: Buckingham.

Cahill, M. i 994. The New Social Policy. Blackwell: Oxford.

Carnegie Enquiry 1993. Carnegie Enquiry into the Third Age-Final Report, Bailey Management Services: Folkestone.

Carstensen, L., Mason, S. E. and Caldwell, E. C. I982. Children's attitudes toward the elderly: an intergenerational technique for change, Educational Gerontology, 8,3, 29I-99.

Centre for Policy on Ageing i984. Home Life: a Code of Practice for Residential Care, Report of a Working Party Sponsored by the DHSS, under the Chairmanship of Lady Kina Avebury. CPA: London.

Chancellor of the Exchequer i 954. Report of the Committee on the Economic and Financial Problems of the Provision for Old Age (Phillips Report). HMSO: London.

Cole, T. 1993. Voices and Visions of Aging: toward a Critical Gerontology. Springer: New York.

Cooper, M., Sidell, M. and the Lewisham Older Women's Health Survey Project. I 994. Lewisham Older Women's Health Survey. EdROP The City Lit: London.

Copper, B. I988. Over the Hill-Reflections on Agism between Women. The Crossing Press: Freedom CA.

Croft, S. and Beresford, P. I99o. From Paternalism to Participation: Involving People in Social Services. Open Services Project and Joseph Rowntree Foundation: London.

Crosland, C. A. R. I956. The Future of Socialism. Jonathan Cape: London.

Department of Health and Social Security (DHSS) r987. Public Support for Residential Care. Report of the Joint Central and Local Government Working Party (The Firth Report), HMSO: London.

Dorling, D. I997. Death in Britain: how Local Mortality Rates have Changed I95os to Ig9os. Joseph Rowntree Foundation: York.

Evandrou, M. I 997. Introduction. In Evandrou, M. (ed) Baby Boomers - Ageing into the 2Ist Century. Age Concern England: London.

Evandrou, M. I 998. Great expectations: social policy and the new millennium elders. In Bernard, M. and Phillips, J. (eds) The Social Policy of Old Age - Moving into the $2 I^{\text {st }}$ Century. Centre for Policy on Ageing: London.

Evers, H. I98I. Care or custody? the experiences of women patients in long-stay geriatric wards. In Hutter, B. and Williams, G. (eds) Controlling Women: the Normal and the Deviant. Croom Helm: London.

Ginn, J. and Arber, S. i 996. Patterns of employment, gender and pensions: the effect of work history on older women's non-state pensions, Work, Employment and Society, Io, $3,469-90$.

Griffiths, R. i988. Community Care: Agenda for Action. HMSO: London.

Health Advisory Service. I983. The Rising Tide: Developing Services for Mental Illness in Old Age. HMSO: London.

Higgs, P. I995. Citizenship and old age: the end of the road? Ageing and Society, 15,4, $535^{-5}$ o.

Hughes, B. and Mtezuka, M. i992. Social work and older women: where have older women gone? In Langan, M. and Day, L. (eds) Women, Oppression and Social Work - Issues in Anti-discriminatory Practice. Routledge: London.

Jamieson, A., Harper, S. and Victor, C. (eds) r 997. Critical Approaches to Ageing and Later Life. Open University Press: Buckingham.

Joseph, A. and Hallman, B. I996. Caught in the triangle: the influence of home, work and elder location on work-family balance. Canadian fournal on Aging, 15,3, 393-4 I 3 . 
Laslett, P. I996. A Fresh Map of Life. Macmillan Press Ltd: Basingstoke, (2nd edition).

Laws, G. I 997. Spatiality and age relations. In Jamieson, A., Harper, S. and Victor, C. (eds) Critical Approaches to Ageing and Later Life. Open University Press: Buckingham.

Le Grand, J. I990. Equity versus Efficiency: the elusive trade-off, Ethics, roo.

Lyons, C. W., Newman, S. and Vasudev, J. i 984 . Impact of a curriculum on aging on elementary school students, Gerontology and Geriatrics Education, 4, 4, 5 I-63.

McEwen, E. (ed) ig9o. Age: the Unrecognised Discrimination. Age Concern England: London.

Marshall, T. H. i 965. Social Policy. Hutchinson: London.

Means, R. I986. The development of social services for elderly people: historical perspectives. In Phillipson, G .and Walker, A. (eds) Ageing and Social Policy - a Critical Assessment. Gower: Aldershot.

Means, R. and Smith, R. I 985. The Development of Welfare Services for the Elderly. Croom Helm: London.

Midwinter, E. I 994. The Development of Social Welfare in Britain. Open University Press: Buckingham.

Midwinter, E. I998. Age and education. In Bernard, M. and Phillips, J. (eds) The Social Policy of Old Age-Moving into the $2 I^{\text {st }}$ Century. Centre for Policy on Ageing: London.

Minkler, M. I996. Critical perspectives on ageing: new challenges for gerontology, Ageing and Society, I6,4, 467-87.

Minkler, M. and Estes, C. L. (eds) rg9 i. Critical Perspectives on Aging: the Political and Moral Economy of Growing Old. Baywood Publishing Company: New York.

Minkler, M. and Estes, C. L. (eds) i 997. Critical Gerontology: Perspectives from Political and Moral Economy. Baywood Publishing Company: New York.

Moody, H. 1992. Ethics in an Aging Society. The Johns Hopkins University Press: Baltimore.

Newman, S. and Marks, R. ig8o. Intergenerational Classroom Teaching Teams: the Effect of Elderly Volunteers, Teachers and Children. Association for Gerontology in Higher Education: Denver.

Newman, S., Faux, R. and Larimer, B. I997. Children's views on aging: their attitudes and values, The Gerontologist, 37,3, 4 I 2-I 7.

NHS and Community Care Act. i990. HMSO: London.

Norton, A., Stoten, B. and Taylor, H. i 986. Councils of Care: Planning a Local Government Strategy for Older People, Policy Studies in Ageing No 5. Centre for Policy on Ageing: London.

Ogg, J., Grimley Evans, J., Jefferys, M. and MacMahon, D. G. i 998. Professional responses to the challenge of old age. In Bernard, M. and Phillips, J. (eds) The Social Policy of Old Age - Moving into the $2 I^{\text {st }}$ Century. Centre for Policy on Ageing: London.

Older Women's League. I 997. The path to poverty: an analysis of women's retirement income'. In Minkler, M. and Estes, C. L. (eds) Critical Gerontology: Perspectives from Political and Moral Economy. Baywood Publishing Company: New York.

OPCS. I 997. 1994-based National Population Projections. HMSO: London.

O’Connor, M. I993. Generation to Generation-Linking Schools with Older People. Cassell: London.

Parker, R. 1990. Elderly people and community care: the policy background. In Sinclair, I., Parker, R., Leat, D. and Williams, J. (eds) The Kaleidoscope of Care: a Review of Research on Welfare Provision for Elderly People. HMSO: London.

Peace, S. and Johnson, J. i 998. Living arrangements of older people. In Bernard, M. and Phillips, J. (eds) The Social Policy of Old Age - Moving into the $2 I^{\text {st }}$ Century. Centre for Policy on Ageing: London. 
Phillipson, C. I982. Capitalism and the Construction of Old Age. Macmillan: London.

Phillipson, C. 1998. Reconstructing Old Age. Sage: London.

Rees, C. r 99 I. Social Workers, Old Women and Female Carers. Social Work Monographs, Norwich: University of East Anglia.

Robb, B. i967. Sans Everything: a Case to Answer. Nelson: London.

Rowntree, B. S. I 947. Old People: Report of a Survey Committee on the Problems of Ageing and the Care of Old People, Oxford University Press: London.

Simey, M. I 998. The politics of ageing. In Bernard, M. and Phillips, J. (eds) The Social Policy of Old Age - Moving into the $2 I^{\text {st }}$ Century. Centre for Policy on Ageing: London.

Stevenson, O. I989. Age and Vulnerability. Edward Arnold: London.

Sullivan, M. I996. The Development of the British Welfare State. Prentice Hall: London.

Titmuss, R. M. 1968. Commitment to Welfare. Allen and Unwin: London.

Townsend, P. I962. The Last Refuge. Routledge and Kegan Paul: London.

Townsend, P. 1963. The Family Life of Old People. Penguin: Harmondsworth.

Townsend, P. and Davidson, N. (eds) ig86. Inequalities in Health: The Black Report. Penguin: Harmondsworth.

Tozer, R. and Thornton, P. i995. A Meeting of Minds-Older People as Research Advisers. Social Policy Reports No 3. York University: Social Policy Research Unit.

Vincent, J. A. I995. Inequality and Old Age. UCL Press: London.

Wagner Report i988. Residential Care: a Positive Choice. Report of the Independent Review of Residential Care. HMSO: London.

Walker, A. I993. Community care policy: from consensus to conflict. In Bornat, J., Pereira, C., Pilgrim, D. and Williams, F. (eds) Community Care: A Reader. Macmillan: London.

Walker, A. I 996. Intergenerational relations and the provision of welfare. In Walker, A. (ed) The New Generational Contract - Intergenerational Relations, Old Age and Welfare. UCL Press: London.

Walker, A. i 997. Speaking for themselves - the new politics of old age in Europe. Beth Johnson Foundation Silver Jubilee Lecture, 7th October.

Walker, A. and Maltby, T. i 997. Ageing Europe. Open University Press: Buckingham.

Walker, A. and Naegele, G. (eds) i 999. The Politics of Old Age in Europe. Open University Press: Buckingham.

Walker, A. and Phillipson, C. I986. Introduction. In Phillipson, C. and Walker, A. (eds) Ageing and Social Policy - a Critical Assessment, Gower: Aldershot.

Walker, A. and Warren, L. I996. Changing Services for Older People-the Neighbourhood Support Units Innovation. Open University Press: Buckingham.

Whitehead, M. i987. The Health Divide. Penguin: Harmondsworth.

Wicks, M. I 994. Social policy and the active society. In Gladstone, D. (ed) British Social Welfare-Past, Present and Future, UCL Press Ltd: London.

Women's National Commission i 992. Older Women, Myths and Strategies - an Agenda for Action. The Women's National Commission: London.

Address for correspondence:

Accepted 22 February 1999

Miriam Bernard and Judith Phillips, Centre for Social Gerontology, School of Social Relations, Keele University, Keele, Staffs, ST $_{5}{ }_{5} \mathrm{BG}$ e-mail:m.bernard@keele.ac.uk j.phillips@keele.ac.uk 